\title{
K-Punk ampliado
}

\author{
Simon Hammond \\ University College London, Londres, Reino Unido \\ Tradução de: Fabrício Silveira \\ Universidade Federal do Rio Grande do Sul, Programa de Pós-Graduação em Comunicação, Porto Alegre, \\ RS, Brasil \\ ORCID: http://orcid.org/0000-0002-9598-8052
}

Tradução de: Matheus Borges

Escritor independente, Porto Alegre, RS, Brasil

ORCID: https://orcid.org/0000-0002-4203-6226

\begin{abstract}
Resumo
"K-Punk at large", aqui traduzido, foi publicado originalmente na New Left Review de julho-agosto de 2019. Simon Hammond, neste texto, traça um amplo panorama da obra do filósofo e crítico cultural inglês Mark Fisher (1968-2017), centrando-se na coletânea K-Punk, lançada em 2018. Examina o trabalho de Fisher num arco de maturação que vai de Realismo Capitalista (2009), seu primeiro livro, a Comunismo Ácido, o livro que deixou apenas esboçado, apreendendo-o no diálogo com Stuart Hall, na tradição dos Estudos Culturais Ingleses.
\end{abstract}

\section{Palavras-chave}

Mark Fisher. K-Punk. Realismo capitalista. Comunismo ácido.

\section{Introdução}

É possível que Mark Fisher, o escritor e crítico cultural inglês, seja conhecido principalmente por seu incisivo primeiro livro, Realismo Capitalista ${ }^{2}$ (2009). Título inaugural de uma editora insurgente, o livro teve um sucesso inesperado e instantâneo e foi traduzido para vários idiomas. Sua crítica abrasiva aos minguantes horizontes imaginativos do neoliberalismo foi formulada durante o triunfo do livre mercado, em seus anos de expansão econômica, e desenvolvida por Fisher em seu blog de culto, K-Punk; o livro, porém, foi publicado num contexto radicalmente diferente, quando o mundo estava se recuperando

\footnotetext{
10 autor agradece a Angus Carlyle, Federico Campagna, William Davies, Jeremy Gilbert, Tariq Goddard, Owen Hatherley, Sadie Plant e Nina Power por sua ajuda na reconstrução da história de vida de Fisher. Não preciso nem dizer que eles não possuem nenhuma responsabilidade por quaisquer erros que possam existir neste texto.

2 Capitalist Realism. Is there no alternative? é o título original.
} 
da crise financeira. Era a hora certa. Como diagnosticou Fisher, o efeito da crise foi ambíguo, apelando, por um lado, a um questionamento do sistema e, no entanto, por meio da resposta governamental, aparentemente confirmando-o como a única alternativa possível. A evolução da situação britânica misturou ambos (os efeitos): no ano seguinte, os conservadores recuperaram o poder e as medidas de austeridade logo provocaram uma nova onda de protestos. Embora fosse um teórico da cultura, Fisher participou do ambiente galvanizado por essa nova situação, emergindo nesse clima ainda mais turbulento como uma presença atípica, porém influente, da esquerda britânica.

Mas após o ressurgimento subsequente da esquerda no parlamento, Fisher permaneceu calado e desapareceu imediatamente, mantendo-se em silêncio. Um segundo livro, Ghosts of My Life (2014), foi publicado depois de Realismo Capitalista; um terceiro, The Weird and the Eerie (2016), apareceu pouco antes de Fisher tirar a própria vida em janeiro de 2017, aos 48 anos. Talvez sua morte pareça ainda mais trágica devido ao momento em que ocorreu: em nível pessoal, porque finalmente ele havia conseguido adquirir uma posição acadêmica relativamente estável, após uma carreira docente precária e pouco sistemática, o que lhe permitiria, junto com sua companheira, criar seu filho em segurança; politicamente, porque sua enfermidade mental havia não apenas inibido seu envolvimento na mudança radical que ele estava esperando, mas o impediu de testemunhar o surgimento de Jeremy Corbyn ${ }^{3}$ nas primeiras eleições daquele verão. Após sua morte, seus amigos e colegas fizeram uma série de relatos emocionantes, muitas vezes esclarecedores, a respeito de Fisher enquanto pessoa e escritor ${ }^{4}$. Até o momento, porém, não parece que tenhamos situado seu trabalho dentro do contexto mais amplo da crítica cultural. A publicação de $K$ Punk: the collected and unpublished writings of Mark Fisher (2004-2016), uma coletânea póstuma e extensa de seus escritos curtos - posts, artigos, ensaios e outros materiais oferece uma oportunidade para examinarmos suas realizações ${ }^{5}$

Como ponto de partida, pode ser útil comparar o pensamento de Fisher com o de Stuart Hall, um dos mais importantes teóricos culturais da geração anterior. Escritores com talento e orientação de esquerda examinaram de maneira profunda a cultura britânica em

\footnotetext{
3 Um político inglês de orientação social-democrata, ligado ao Partido Trabalhista [N.T.].

4 Ver especialmente Alex Niven, "Mark Fisher, 1968-2017", Jacobin, 19 de janeiro de 2017; Owen Hatherley, "Writing of a sort that wasn't supposed to exist anymore", Ceasefire, 17 de janeiro de 2017; Jeremy Gilbert, "My friend Mark", post de 11 de março de 2017 no blog jeremygilbertwriting.

${ }^{5}$ Mark Fisher, K-Punk: the collected and unpublished writings of Mark Fisher (2004-2016), Darren Ambrose (ed.), Londres, 2018. A edição espanhola está em curso, com previsão de publicação em três volumes pela Caja Negra Editora, dos quais, até o momento, publicou-se apenas o primeiro: K-Punk. Escritos reunidos e inéditos, volume 1, Buenos Aires, 2019, que reúne artigos sobre literatura, cinema e televisão.
} 
seu sentido mais amplo, bem como suas condições de possibilidade: Hall analisou a base da hegemonia thatcherista como uma "solução" para o mal-estar do capitalismo britânico; Fisher mapeou a paisagem que emergiu após a consolidação do thatcherismo através do Novo Trabalhismo. Ambos liam a cultura popular - "as artes populares", como Hall as definia - para procurar o que Fisher chamava de "traços de outras possibilidades", de outros mundos. Hall falava em aplicar os procedimentos da crítica cultural às obras populares para distinguir aquelas que tinham uma qualidade real daquelas que eram meramente ostensivas ou dissimuladas. Buscar essa diferença de valor é crucial nos escritos de Fisher sobre a música contemporânea ${ }^{6}$. Ambos, de maneiras diferentes, eram estrangeiros. Hall, nascido na Jamaica, procedia de uma família refinada de classe média, que contava com serviço doméstico; ele desembarcou com uma bolsa Rhodes na Grã-Bretanha da década de 1950, onde havia cartazes nas janelas das pensões que diziam "negros não". As origens de Fisher junto à classe trabalhadora em East Midlands também lhe proporcionaram a visão privilegiada de um forasteiro; mas, embora geograficamente estivesse mais perto da metrópole, sua origem lhe dava uma sensação muito mais visceral e permanente de estranhamento e marginalidade. Ambos combinavam ensino com intervenções no ambiente cultural da esquerda: no caso de Hall, nas revistas Universities e Left Review, NLR, Marxism Today e Soundings; no caso de Fisher, na blogosfera e na editora Zero Books, seguido de seu avatar, Repeater, nas editoras independentes que fundou com Tariq Goddard e outros amigos e, mais tangencialmente, nas revistas Mute e Wired e na think tank Compass.

As profundas diferenças entre eles são reveladoras da trajetória daquela cultura que era seu tema comum. Hall, nascido em 1932, atingiu a idade adulta num período de otimismo e maiores possibilidades para a esquerda. A economia britânica estava à beira de seu crescimento no pós-guerra, o estado de bem-estar era ainda novo e radiante, os sindicatos estavam no topo de seu poder. 0 enorme sucesso internacional da música pop britânica de origem trabalhadora - Beatles, Stones, The Who - cimentava a solidez cultural do período, enquanto proliferava uma cultura jovem florescente e, no teatro, na televisão e no cinema, apostava-se em trabalhos experimentais. Universidades, institutos politécnicos e escolas de arte proliferavam. No final da década de 1950, Hall havia deixado sua tese sobre Henry James, em Oxford, para trabalhar para as revistas de esquerda, para ensinar idiomas numa escola secundária masculina de Londres, situada no escalão mais baixo de um sistema

\footnotetext{
${ }^{6}$ Mark Fisher, Ghosts of My Life. Writings on depression, hauntology and lost futures, Londres, 2014, p. 29. Edição em castelhano: Los Fantasmas de Mi Vida. Escritos sobre depresión, hauntología y futuros perdidos, Buenos Aires, 2018; Stuart Hall e Paddy Whannel, The Popular Arts, Londres, 1964, p.p. 22, 37-44.
} 
definido pela classe social e depois para ensinar cinema na Chelsea Technical College ${ }^{7}$. Em 1964, convencido por The Popular Arts - uma tentativa, em coautoria com Paddy Whannel, de integrar cinema e jazz no currículo escolar -, Richard Hoggart contratou Hall como pesquisador no recém-inaugurado Centro de Estudos Culturais Contemporâneos de Birmingham (CCCS), pagando-lhe o salário de seu próprio bolso. Quando Hoggart deixou o centro para trabalhar junto à Organização das Nações Unidas para a Educação, a Ciência e a Cultura (UNESCO), Hall se tornou diretor até 1979, ano em que assumiu a cadeira de sociologia na Open University. Ele sempre se beneficiou de constante apoio institucional e, como intelectual público na era da televisão, participava regularmente dos debates nacionais.

Fisher, nascido em 1968, cresceu em um período que ele caracterizaria de forma convincente como uma era de desintegração. 0 determinante crucial de sua formação foi uma adolescência que se desenrolou entre o ponto alto e o subsequente outono de uma era, pois a economia mundial passou de um longo período de expansão para um longo período de declínio, o que causou a crise do pacto do pós-guerra. Os parâmetros exatos dessa periodização estavam sujeitos a alterações, mas o arco costumava ser claramente demarcado: "1979-1980", ele escreveu num ensaio sobre os sons depressivos da banda póspunk Joy Division, foi "um limiar, o momento em que todo um mundo (social-democrata, fordista, industrial) se tornou obsoleto e começou-se a vislumbrar os contornos de um novo mundo (neoliberal, consumista, informatizado)"8. A economia havia passado pelo liquidificador de Thatcher com o resultado conseguinte de altos níveis de desemprego e crescente insegurança; os sindicatos haviam sido destruídos, a austeridade e a mercantilização tornaram-se condições permanentes e as universidades foram impiedosamente pressionadas. O cenário da cultura de massas era cada vez mais monopolizado e comercializado, dominando uma cena subcultural fragmentada na qual classe e cultura haviam, em grande parte, se desarticulado. Em contraste com Hall, o próprio Fisher, no que diz respeito ao relacionamento que mantinha com as instituições, com o público e com as formas culturais que escolhia, e em relação a muitos dos fenômenos culturais que examinou, era uma figura subcultural. Relegado a um trabalho precário, seus escritos foram possibilitados posteriormente pela Internet e a reputação que obteve tinha

\footnotetext{
7 Hall descrevia o ensino secundário como uma "experiência que lhe trazia de volta à terra", que lhe tornou "agudamente consciente do conflito entre as normas e as expectativas da educação formal e as complexidades do mundo real em que habitam as crianças e os jovens". Essa experiência marcaria a obra sobre as subculturas adolescentes que dirigiu em Birmingham. S. Hall e P. Whannel, The Popular Arts, cit., p. 13.

${ }^{8}$ M. Fisher, Ghosts of My Life, cit., p. 50.
} 
vigência nas margens da academia e longe do alcance do radar do jornalismo hegemônico. Seu trabalho também era tipicamente subcultural em razão do investimento emocional que gerava, produzindo um tipo de adesão mais afim à música pós-punk e à música eletrônica que compunham o território próprio de sua crítica.

No caso de ambas as figuras, que operavam em diferentes pontos da restauração neoliberal, essa era a realidade política que consumia suas energias. Em suas nítidas reflexões sobre o surgimento, as modalidades, os efeitos e a resistência do neoliberalismo, ambos concordaram com o primado da cultura como ferramenta analítica e como substância de suas conjecturas. De maneira mais destacada, a oposição que ambos organizaram pode ser caracterizada como explicitamente modernizadora: sua atenção se concentrou na necessidade de se adaptar aos tempos, enquanto suas críticas se dirigiam ao que identificavam como sendo o fracasso da esquerda na hora da capturar o caráter da época e dar-lhe uma resposta mais apropriada. Críticos do Partido Trabalhista, a partir de seu flanco esquerdo, tentaram influenciar na sua direção durante os períodos em que este não governava: Hall durante o governo conservador da década de 1980 e início da década de 1990; Fisher durante o período subsequente, que começou em 2010 e continua no momento em que escrevo este artigo. Foi, de fato, durante esse compromisso paralelo com a política parlamentar e com os aspectos práticos da mudança política que Fisher interatuou mais claramente com o trabalho de Hall, não apenas prestando-lhe homenagem, mas também elogiando a relevância duradoura de seus diagnósticos e prescrições. Tendo iniciado sua vida intelectual como antagonista dos Estudos Culturais e depois seguindo uma trajetória distanciada de Hall, Fisher encontrou, nos últimos anos de sua vida, uma causa comum com seu antecessor.

\section{Um garoto das Midlands}

Fisher nasceu em Leicestershire e cresceu em Loughborough, uma pequena cidade semi-industrial. Filho de uma família conservadora em sentido estrito - seu pai era técnico de uma empresa local, sua mãe trabalhava com limpeza doméstica -, Fisher foi ao instituto de ensino secundário do bairro, recebendo o que mais tarde recordou como "uma tediosa cultura média". A respeito de suas experiências políticas formativas, Fisher aludia ao "sentimento amargo de uma completa derrota existencial" ante o desastre eleitoral trabalhista de 1983 e confessou que não podia recordar o dia em que, dois anos mais tarde, 
fracassou a greve mineira e ele sequer "se pôs a chorar" ${ }^{\text {. }}$. No entanto, num primeiro momento, a cultura havia se livrado das arremetidas de Thatcher. As revistas musicais britânicas floresciam durante os anos da adolescência de Fisher. Em New Musical Express, Ian Penman e Paul Morley eram intelectuais autodidatas cujos escritos apaixonados e rigorosos sobre cultura musical - o que constituiu um modelo precoce mas duradouro para Fisher - ganharam reputação pelo emprego frenético e promíscuo da filosofia e da teoria continental. "Não é para me lamentar, mas, para alguém de minha procedência, é difícil ver outro lugar de onde esse interesse poderia ter me atingido", refletia Fisher, mais tarde ${ }^{10}$.

Esta escritura excitante sobre música coincidiu com o último florescimento da televisão britânica, quando a BBC2 e o Channel4, criados para abordar uma programação alternativa, competiam por primazia cultural. Fisher recorda ter acessado o cinema europeu de artes e ensaios nos programas da madrugada. A potência desses primeiros encontros é algo ao qual alude com frequência em seus escritos: "é possível reproduzir, mais tarde em sua vida, o impacto que tiveram os livros lidos, os discos e os filmes ouvidos ou vistos entre os quatorze e os dezessete anos?"11. Um refrão recorrente em seus textos é o pesar sobre o desmantelamento da infraestrutura cultural que ele considerava que havia lhe formado projetos posteriores seriam tentativas subculturais de replicá-la - e sobre o retrocesso cultural que ele entendia como coincidente com o que se verificava nos âmbitos político e social.

A Universidade de Hull, onde estudou Literatura e Filosofia, entre 1986 e 1989, não era um bastião da educação de elite, mas Fisher - ainda que compartilhasse interesses com seus amigos, administrasse um club, dirigisse um programa noturno de rádio e escrevesse para a revista de arte da universidade - experimentou, não obstante, o tipo de deslocamento social que Richard Hoggarth havia analisado em The Uses of Literacy (1957). Muitos anos depois, em seu blog, descreveu a "angústia" e a "alienação" que isso provocava. Em seu caso, ele assinalava, havia uma forma dupla de deslocamento, na qual se misturava também a mudança econômica e social: "inclusive se tivesse ficado em minha cidade natal, não poderia

\footnotetext{
9 Blog, “Don't vote, don't encourage them”, 04 de maio de 2005, em M. Fisher, K-Punk: the collected and unpublished writings of Mark Fisher (2004-2016), cit., p. 429; "Test Dept.: where leftist idealism and popular modernism collide", Frieze, 25 de setembro de 2015, ibid., p. 416.

10 Blog, "Why K?", 16 de abril de 2005, ibid., p. 31.

11 Blog, "Book meme”, 28 de junho de 2005, ibid., p. 38. Uma de suas lembranças era de ter visto Hall na televisão aberta: "Para alguém como eu, nascido em 1968, que foi seduzido pela teoria através das transmissões da televisão pública, pelas citações a Derrida e Baudrillard feitas pelos autodidatas da imprensa musical, e pelo pós-punk, com suas muitas alusões à arte, à literatura e ao cinema experimental, não parecia nada especial que Hall fosse uma voz e um rosto habituais da BBC", porém, complementa, "as forças que apagariam a cultura que lhe permitia ocupar uma posição assim na grande mídia já estavam em marcha", M. Fisher, The Stuart Hall Project, BFI, 2014, p. 1-2.
} 
sequer ter me acomodado ao 'mundo arraigado da classe trabalhadora', porque esse mundo já não existia"12. Nas primeiras linhas de um ensaio que evocava essa época, escrito em 2014, descreveu a gradual perda de seu sotaque das East Midlands, dado que saíra da casa dos pais, como uma conquista "carregada de ambivalência e vergonha"13. Um permanente sentimento de desgarramento modelou sua relação com as instituições.

Depois de Hull, Fisher se mudou para Manchester, oscilando entre empregos temporários, tocando em grupos de música pop e estudando para se creditar, algum dia, como professor. Uma etapa seguinte de sua vida se catalisou aí, em 1992, quando assistiu uma conferência de Sadie Plant (Plant recorda que havia exposto algo sobre Kathy Acker). Plant, então com 28 anos, estava dando aulas no reestruturado Departamento de Estudos Culturais de Birmingham. Fisher começou a fazer ali um mestrado, logo em seguida, sob sua orientação. Os dias gloriosos da estadia de Hall em Birmingham, contudo, tinham acabado há muito tempo. Na década de 1990, a vitalidade intelectual do Centro havia evaporado e sua transformação em departamento o havia afogado em responsabilidades administrativas. A disciplina da qual havia sido pioneiro perdera grande parte de seu poder crítico e, em alguns casos, estava reduzida a um mero elogio da diversidade do mercado ${ }^{14}$. Nem o primeiro livro de Plant - uma história intelectual crítica do envolvimento dos autores pósmodernos com os conceitos revolucionários situacionistas -, nem sua nova e iconoclasta obra sobre cibernética e futuridade radical tinham muito em comum com o que haviam se convertido os Estudos Culturais ${ }^{15}$. Quando, em 1995, Plant foi contratada como investigadora sênior em Warwick, Fisher, acompanhando outros estudantes de pósgraduação, se mudou junto com ela (fugiram, desgostosos, como Fisher, mais tarde, expressaria). Nesse novo ambiente, os "cult-studs" (estudos culturais) eram depreciados como parte de um atrasado sistema intelectual estabelecido.

\footnotetext{
12 Blog, "Can’t stay long”, 10 de fevereiro de 2008, não-incluído em K-Punk: the collected and unpublished writings of Mark Fisher (2004-2016), cit.

13 "Review: Sleaford Mods' Divide and Exit and chubbed up: the singles collection", Wired, abril de 2014, ibid., p. 411.

14 O próprio Hall advertiu contra essa tendência na década de 1990, recordando a seus sucessores que a cultura popular também era "o lugar, por excelência, da mercantilização", Stuart Hall, "What is this 'black' in black popular culture?", em David Morley e Kuan-Hsing Chen (eds.), Stuart Hall: critical dialogues in Cultural Studies, Londres, 1996, p. 469.

${ }^{15}$ Sadie Plant, The Most Radical Gesture: the Situationist International in a postmodern age, Londres, 1992; seu manifesto ciborgue-feminista Zeros and Ones, seria publicado em 1997.
} 


\section{Entre os aceleracionistas}

Em Warwick, Plant montou o Cybernetic Culture Research Unit (CCRU) com um grupo acidental de colaboradores unidos em torno de um jovem professor associado do Departamento de Filosofia, seu amigo Nick Land - "Nosso Nietzsche", na descrição retrospectiva de Fisher. Land foi o autor de The Thirst for Annihilation: George Bataille and virulent nihilism (1992). Ao contrário de Plant, Land não tinha um histórico de adesão ou lealdade à esquerda. Fisher escreveria em várias ocasiões sobre seu "encontro perturbador" com Land, a emoção de seus escritos e suas ideias em contraste com tanto trabalho acadêmico formal, a inspiração fornecida pelo modo como entrelaçava cinema e ficção com teoria e filosofia. Num ensaio de 2012 voltou a falar nos "textos antimarxistas extraordinários" que Land produziu naquele tempo, as "provocações teórico-ficcionais" que, argumentava Fisher, continuavam proporcionando um antagonismo produtivo ${ }^{16}$. Baseandose em Libidinal Economy (1974) de Lyotard e no Anti-Oedipus (1972), de Deleuze e Guattari, bem como na música jungle e na ficção cyberpunk, a escritura frenética do CCRU demandava uma aceitação aceleracionista das energias dinâmicas e radicais do capitalismo; Fisher, mais tarde, falou sobre sua "antipolítica exuberante"17. 0 grupo de Warwick consolidou-se em oposição não apenas ao carácter acomodatício dos Estudos Culturais e às contorções intelectuais à moda do pós-modernismo acadêmico, mas opondo-se também aos paradigmas e ao culto devoto de uma esquerda desorientada ${ }^{18}$.

Land assumiu a direção do CCRU em 1997, depois que Plant decidiu seguir carreira como escritora independente e se tornou a principal figura da Unidade. Sob a tutela de Land, o CCRU tomou uma direção ainda mais hermética, incorporando elementos da matemática, do pensamento místico e do ocultismo, tudo empregado a serviço da celebração exaltada do mercado, tudo modulado pela ficção científica, onde o capital era tido como o verdadeiro agente da história: “a revolução maquínica deve, portanto, ir na direção oposta à regulação socialista; pressionando a favor de uma mercantilização cada vez mais desinibida dos

\footnotetext{
${ }^{16}$ FISHER, M..,"Nick Land: mind games", Dazed and Confused, maio de 2011; M. Fisher, "Post-capitalist desire” In: CAMPAGNA, Federico; CAMPIGLIO, Emanuele (eds). What We are Fighting For: a radical collective manifesto, Londres, 2012, p. 132.

17 "They can be different in the future too: interviewed by Rowan Wilson", Ready Steady Book, 2010, em M. Fisher, K-Punk, cit., p. 629.

18 "A alienação utilizada para diagnosticar as condições de uma população que se tornava estranha para si mesma levava a um prognóstico que ainda prometia uma recuperação", escreviam Plant e Land em 1995. "Mas isso já não é mais assim. Agora todos somos estranhos, não mais alienados, mas alienígenas, simplesmente iludidos para mostrar uma lealdade desmoronada às tradições entrópicas". Conferir "Cyberpositive", em Robin Mackay e Armen Avanessian, (eds.), \#Accelerate: The Accelerationist Reader, Falmouth, 2014, p. 308.
} 
processos que estão destroçando o campo social"19. Além do surgimento de novas tecnologias e de suas formas culturais correspondentes, a conjuntura do CCRU foi o período posterior à Guerra Fria, de exuberância irracional da bolha tecnológica, de decomposição do estado de bem-estar social e do movimento trabalhista. Em tais circunstâncias, mais do que uma narrativa de declínio e queda, Fisher sentiu-se atraído pela possibilidade de postular uma assunção inebriante do futuro, o qual constituiria um bálsamo para as perdas de seus anos de formação. Sua tese de doutorado, Flatline Constructs. Gothic materialism and cybernetic theory-fiction (2018), uma análise das obras seminais do cyberpunk entendidas como contribuições à filosofia anti-humanista, é um exemplo perfeito das preocupações do CCRU.

A fundação da Unidade coincidiu com as primeiras publicações de Fisher. Estas lhe proporcionaram uma ideia mais concreta da política cultural futurista do grupo, que buscava sua inspiração em Blade Runner, de Ridley Scott, e em Neuromancer, de William Gibson, assim como nas últimas mutações da música eletrônica britânica. Num artigo para New Statesman, Fisher denunciou o britpop, um movimento cujos líderes logo estariam sorrindo ao lado de Tony Blair, em Downing Street, como "indies reacionários", encontrando em suas obras um pessimismo a respeito do presente que não existia na cena de música eletrônica, mais orientada para o futuro. Num texto para a Wired, elogiou essa última por operar à margem das estruturas empresariais mediante o emprego das novas tecnologias, um deslocamento que Fisher descrevia como a evolução de uma "massa crítica do cyberpunk"20. 0 peso político dessa afirmação ficava mais explícito num artigo mais extenso para New Statesman, no qual elogiava a "colagem proletária e agressiva de batidas hiperativas, samples fantasmagóricos e eletrônica ominosa" dos subgêneros do "lado obscuro" por encontrarem "um vocabulário para os tempos sombrios". Num clássico détournement do CCRU, Fisher celebrou esse carácter tenebroso pelos indícios de futuro que oferecia. Supor que as mudanças da década de 1990 "devem ser negativas" era "engolir a velha história que tanto os socialistas quanto os conservadores ainda não nos ofereceram": "nosso horror diz respeito unicamente aos estertores de morte da velha ordem. Quem sabe o que trará o novo?"21.

Ainda que o CCRU possuísse aspectos em comum com o CCCS de Hall e Hoggart em seus primeiros dias - um grupo de professores e estudantes de pós-graduação trabalhando

\footnotetext{
${ }^{19}$ Nick Land, "Machinic desire”, Textual Practice, vol. 7, núm. 3, 1993, p. 480.

${ }^{20}$ M. Fisher, "Indie reactionaries", New Statesman, 7 de julho de 1995; M. Fisher, "Beyond the face”, Wired, junho de 1995.

${ }^{21}$ M. Fisher, "Hello darkness, our new friend", New Statesman, 11 de março de 1994.
} 
num espírito interdisciplinar e colaborativo, fortalecidos por correntes da teoria continental e por novas perspectivas culturais, orientados por uma sensação de mudança vertiginosa -, a trajetória da Unidade de Warwick foi inversa à trajetória do Centro de Birmingham. Desaprovado pelo Departamento de Filosofia após a saída de Sadie Plant, o CCRU efetivamente cortou vínculos com Warwick em 1997 e mudou-se para Leamington Spa, onde alugou uns quartos acima de uma filial do The Body Shop, antes de se dissolver três anos depois ${ }^{22}$. A cultura institucional em que essas unidades operavam haviam sido transformadas. O CCCS emergiu num período de crescimento universitário sob o "modelo de difusão cultural do estado de bem-estar social", num tempo de expansão das instituições e de regimes progressistas de ensino ${ }^{23}$. Tudo isso havia terminado com a ofensiva de Thatcher na década de 1980: as universidades foram submetidas a cortes drásticos nos gastos; os fundos estavam vinculados às metas e às reformas; os "exercícios de avaliação das pesquisas" se tornaram obrigatórios. A disciplina do mercado e a instrumentalização do conhecimento estavam agora na ordem do dia. Nesse clima inóspito, o grupo deliberadamente esotérico do CCRU, que se opunha ao que considerava como limitações mortais da academia, não teria oportunidade de sobreviver. Land abandonou a vida universitária, encontrando posteriormente um nicho profissional em Shanghai, onde seu anti-humanismo niilista se fundiria com os estratos mais desmesurados da direita virtual.

\section{A curva do futuro}

Fisher se movimentou na direção política oposta. 0 que ele reteve do período do CCRU foi, sobretudo, uma compreensão do capitalismo como a realidade inescapável do presente, combinada com um firme compromisso com o futuro. Mais tarde, isso assumiria a forma de um desejo (à esquerda) de recuperar o manto da modernidade, de desatar o futuro de sua captura pelo neoliberalismo. "É necessário" - argumentava ele, numa entrevista de 2010 - "chegar até o final do pós-fordismo e seguir olhando mais além, especialmente nos momentos em que parece não haver mais nada à nossa frente"24. A sensibilidade distintiva de sua obra foi forjada na conjunção desse futurismo com um sentido agudo de perda da

\footnotetext{
${ }^{22}$ Há um perfil de Fisher, "um rapaz bem-educado que fala com uma urgência evangélica e gestos de mão agitados”, em um vívido retrato do CCRU, antes de ser fechado, feito em 1999 pelo jornalista musical Simon Reynolds, encomendado por Lingua Franca: "Renegade Academia: The Cybernetic Culture Research Unit", publicado no blog de Reynolds, Energy Flash, em 3 de novembro de 2009.

${ }^{23}$ Ver: COLLINI, Stefan. What Are Universities For?, Londres, 2012. p. 33, 22

${ }^{24}$ Entrevista com Rowan Wilson, K-Punk, p. 633-4.
} 
estrutura de sentimentos de sua juventude, dessa cultura social-democrata cujos estertores mortais ele testemunhara.

Nisso havia uma semelhança subjacente com as atividades de Hall durante o mesmo período: as conjecturas sobre os "novos tempos" tinham o mesmo objetivo de barrar o pensamento antigo. Nas análises proféticas reunidas em The Hard Road to Renewal (1988), Hall definia o thatcherismo como "a abertura de um novo projeto político à direita, a construção de uma nova agenda", que exigia uma modernização ainda mais abrangente da esquerda ${ }^{25}$. Na opinião de Hall, era essa a razão de retornar ao pensamento de Gramsci após a onda revolucionária de 1917-1924, não "para que ele pensasse por nós", mas porque Gramsci suscitava as perguntas exatas com as quais uma esquerda renovada precisaria lidar, "dirigindo nossa atenção sem vacilar àquilo que é específico deste momento", o modo "como forças diferentes se agrupam, conjunturalmente, para criar o novo terreno no qual se deve formar uma nova política"26. A formação de Hall era de inspiração histórica e, apesar de Althusser, de recorte humanista, enquanto a formação de Fisher era oposta: o CCRU se ocupava principalmente em unir a filosofia anti-humanista à cibercultura emergente e, apenas ocasionalmente, interessava-se por processos históricos mais largos. Ainda assim, ambos estavam profundamente engajados com o problema da novidade e, quanto mais Fisher trabalhava nisso - sendo seu terreno originário, acima de tudo, a cultura popular, especialmente a música, e não o campo político -, mais se envolvia com questões relativas à mudança histórica.

\section{Encontrando um meio}

Depois de concluir seu doutorado, Fisher se mudou para a periferia ao sul de Londres. A princípio, era por disposição e falta de recursos que Fisher vivia e trabalhava nos arredores da capital. 0 significado cultural dos territórios às margens da metrópole, as inovações forjadas nos subúrbios e nas regiões afastadas, seriam, contudo, um tema proeminente em suas críticas. Sem romantizar - antes, ao contrário disso -, ele notaria que Siouxsie and the Banshees e David Bowie tinham vindo do subúrbio de Bromley, também no

\footnotetext{
250 projeto do thatcherismo "não era simplesmente o de comandar os aparelhos do Estado", escrevia Hall. De fato, em seus estágios iniciais, foi organizado em oposição ao Estado, que, na visão thatcherista estava profundamente corrompido pelo keynesianismo. 0 projeto era antes o de "transformar o estado para reestruturar a sociedade": Stuart Hall, "Gramsci and us", The Hard Road to Renewal: thatcherism and the crisis of the left, Londres e Nova York 1988, p. 163.

${ }^{26}$ Stuart Hall, "Gramsci and us", p. 162-3.
} 
sul londrino; Japan, outro item básico de seu cânone cultural, era da vizinha Catford; J. G. Ballard, o autor mais frequentemente citado em $K$-Punk, que proclamou que "a periferia é onde o futuro se revela", residiu ainda mais longe, em Shepperton.

Em 2003, durante um período de depressão, Fisher criou o blog K-Punk. 0 "espectro maligno" da depressão o assombrava desde a adolescência e ele achava a vida "pouco suportável" durante esse período, com o blog fornecendo sua "única conexão com o mundo"27. 0 "K" de K-Punk, que serviu como um título e uma identidade pessoal, foi uma derivação de $\kappa \cup \beta \varepsilon \rho$, a expressão grega para "cyber", invocada num sentido amplo - não apenas como um gênero, mas como uma tendência social e cultural muito maior, facilitada pelas novas tecnologias. Suas reflexões penetrantes sobre cultura e conceitos teóricos logo conquistaram seguidores dedicados. Mantendo o espírito contestatório do CCRU e seu idioma de alta teoria aplicada à cultura popular, Fisher abandonou o que mais tarde chamou de "jargão intransigente"28. A evolução de sua reflexão política trouxe outras mudanças incrementais. 0 pensamento de Fisher se tornou cada vez mais animado pelo desejo de transitar do individual ao coletivo, para reavivar a solidariedade numa era de atomização. Os primeiros posts do blog, impressos agora na nova coletânea, exibem um resíduo da aspereza do CCRU; mas há também um legado mais longo e menos proeminente de temas, como a cadência dada pela ficção científica ao funcionamento da ideologia, da classe e da mudança social - uma licença poética também ativa no trabalho de Land. 0 sentimento de alegria de Fisher junto à velocidade do contemporâneo, enquanto isso, diminuiu nos anos do Novo Trabalhismo, sendo substituído por uma preocupação com a estabilidade cultural e política.

Através de K-Punk, Fisher se tornou uma figura imprescindível numa mancha on-line de jovens intelectuais precarizados. Sua rede de blogs aglutinava um fórum para animadas discussões sobre música, cinema, teoria, filosofia e política; o formato se prestava à improvisação e, frequentemente, à experimentação de outros modos de escrita e de pensamento. Para Fisher, isso representou uma nova instância subterrânea da infraestrutura jornalística que prevalecera durante sua juventude; na descrição dada por Simon Reynolds, que contribui com o prefácio à nova coletânea, era "a imprensa musical no exílio"29. Muito jovem para escrever para o New Musical Express ou o Melody Maker durante seus respectivos dias de glória, Fisher foi, em certo sentido, um sujeito descompassado com

${ }^{27}$ Ghosts of My Life, p. 28; Blog, “One year later...”, 17 de maio de 2004, K-Punk, p. 693.

28 Entrevista com Rowan Wilson, K-Punk, p. 629.

${ }^{29}$ Simon Reynolds, Foreword, K-Punk, p. 16. 
o seu próprio tempo, que atingia a maioridade como intelectual numa época e num ambiente inóspitos. É sintomático que New Statesman, para a qual ele escreveu seus primeiros artigos, tenha alterado suas condições de trabalho; sob nova redação, tornou-se o diário mais eficiente para o Novo Trabalhismo. As relações mal-humoradas de Fisher com a "mídia antiga" se tornaram um assunto intermitente de seu blog; porém, aqui, livre do controle editorial, foi capaz de abordar uma variedade eclética de assuntos de sua própria escolha, de Burroughs a Spinoza, dos ataques terroristas em Londres até a pornografia ${ }^{30}$. Politicamente, Fisher podia ser muito mais selvagem do que Hall. Contestando a necessidade de votar em Blair em 2005, perguntava: "mas qual é a ameaça que os Conservadores de Howard representam? Eles vão suspender o habeas corpus? Não podem! Toneeeeeee já fez isso! Irão agradar descaradamente a direita nos temas da imigração? Bem, sim, isso é o que já está fazendo o Joker de Cara Histérica"31. Musicalmente, seu escopo se estendeu dos novos lançamentos às diversas linhas de inovação, que se seguiram aos anos sessenta, do Glam, Punk, Pós-Punk, Novo Romantismo e Gótico até o "hardcore continuum" da música eletrônica, que começou com as raves e continuou através do jungle e do two steps. Lia vorazmente: Baudrillard, Ballard, Jameson, Sartre, Fukuyama, Veblen, Kant. Zizek lhe interessava em particular porque trabalhava com os mesmos materiais conceituais do CCRU, desde uma abordagem, porém, de esquerda. Numa resenha de 2004, em Mute, elogiou os livros de Zizek sobre a guerra ao terror como "intervenções imediatas nas questões geopolíticas mais prementes" e como "um maravilhoso anúncio do que a teoria pode fazer" 32 .

Durante esse período, Fisher trabalhava em institutos de formação profissional, no grande distrito de Orpington, outra área suburbana de Londres. Outra vez mais se percebe o contraste geracional existente entre a experiência de intelectuais de esquerda anteriores, que passaram períodos formativos trabalhando na educação de adultos, além dos limites do sistema universitário. Para Edward Thompson e Raymond Williams, o terreno foi a Associação de Educação dos Trabalhadores (Worker's Education Association), organização de educação não-formal, historicamente ligada ao movimento trabalhista. Fisher, ao contrário, estava ensinando jovens de 16 a 19 anos, numa subdivisão de nível inferior do sistema estatal de ensino. Estudantes desmoralizados, desfalecidos em suas mesas, lutavam

\footnotetext{
${ }^{30}$ Blog, “Choose your weapons”, 12 de agosto, 2007, K-Punk, p. 354.

31 "Don't vote, don't encourage them", K-Punk, p. 429.

32 Fisher, "The Big Other \& 'unknown knowns'”, Mute, 22 de julho 2004, resenhas de Zizek, Welcome to the Desert of the Real e Iraq: The Borrowed Kettle.
} 
para ler mais do que poucas frases. Uma entrevista que concedeu durante os primeiros dias de K-Punk registrou sua admissão de que era um "trabalho difícil e desafiador", mas não considerava sua posição subordinada em comparação com uma colocação acadêmica "mais autêntica"33. A experiência foi radical e Fisher, mais tarde, citou esse trabalho como elemento fundamental em sua reorientação política. Isso coincidiu com a implementação das reformas neoliberais no setor: seu blog incluía reflexões sobre o clima de "maior precarização, de novas políticas punitivas, contra adoecimentos, de professores sendo demitidos e forçados a se inscrever novamente em seus empregos, da imposição de mais e mais metas", e lamentou a degradação de instituições que historicamente ofereceram educação alternativa àqueles de origem semelhante à sua ${ }^{34}$.

\section{Um novo manifesto}

Essas vicissitudes caracterizaram de modo fundamental o conteúdo de Realismo Capitalista. Frequentemente usado em K-Punk, esse termo foi definido no livro como "a ampla percepção de que não apenas o capitalismo é o único sistema político e econômico viável, mas também de que agora é impossível imaginar uma alternativa coerente a ele"35. 0 futuro, dentro dessa perspectiva, seria incapaz de nos proporcionar algo novo. A terminologia chamativa era uma das características distintivas do trabalho: não apenas o título em si, mas uma variedade de conceitos recém-cunhados ou reaproveitados - ontologia empresarial, stalinismo de mercado, privatização do estresse. 0 emprego da cultura popular como campo de evidências e exemplos era outra de suas marcas. O livro começava com uma exegese brilhante do filme de Alfonso Cuarón, Children of Men (2006), baseado no romance distópico de P. D. James: um evento catastrófico resultou em esterilidade em massa e não haverá novas gerações. Fisher lê isso metaforicamente, entendendo-o como o deslocamento de uma outra ansiedade: quanto tempo uma cultura pode persistir na ausência de algo novo? Para T. S. Eliot - a esterilidade também era um tema de The Wasteland (1922) -, a falta da novidade nos rouba nosso passado: a tradição não vale nada quando não é mais contestada e modificada.

Fisher reconhecia que o termo "realismo capitalista" poderia subsumir-se na concepção de Fredric Jameson do pós-modernismo como a "lógica cultural do capitalismo

\footnotetext{
33 Blog, “Why K?”, K-Punk, p. 32.

${ }^{34}$ Blog, "Spectres of Marker and the reality of the Third Way", 18 de fevereiro, 2006, K-Punk, p. 163.

35 Mark Fisher, Capitalist Realism: is there no alternative?, Londres, 2009, p. 2.
} 
tardio", que também enfatizava o fracasso do futuro. Mas argumentava que, agora, uma geração depois, os processos analisados por Jameson haviam se tornado tão agravados que sofreram uma mudança de natureza. Fisher destacou três alterações em particular. Quando Jameson estava escrevendo sobre o pós-modernismo, em meados dos anos 1980, ainda existiam alternativas políticas - o bloco soviético, o movimento dos trabalhadores organizados -; o século XXI implicava uma esterilidade cultural e política muito mais profunda e muito mais difundida. Em segundo lugar, o pós-modernismo, como Jameson descreveu, ainda estava envolvido numa batalha contra o modernismo, atacando-o em nome da "diversidade" e da "multiplicidade". Em 2008, essa vitória já havia sido conquistada há muito tempo - o "realismo capitalista não encena mais esse tipo de confronto com o modernismo". Em terceiro lugar, se é verdade que o capitalismo não possui "um lado de fora", desejos e aspirações não podem ser incorporados, mas já estão "pré-estabelecidos", preventivamente pré-formatados. Termos como "alternativo" ou "independente" não designam mais algo fora da cultura vigente; antes, são seus estilos dominantes ${ }^{36}$.

O conceito de "realismo capitalista" havia sido usado de maneira irônica na década de 1980 para designar o mundo visual da publicidade norte-americana, como contraponto à arte soviética. Para Fisher, era "como uma atmosfera penetrante, condicionando não apenas a produção da cultura, mas também a regulamentação do trabalho e da educação; agia como uma espécie de barreira invisível que limitava o pensamento e a ação". Como então combatê-lo? Fisher impacientava-se com o movimento antiglobalização, considerava os protestos contra o G7 "um ruído de fundo carnavalesco para o realismo capitalista", impondo demandas que não esperava que fossem atendidas - enquanto o "imobilismo" defensivo dos estudantes franceses, tentando bloquear as reformas liberais, falhava em oferecer uma saída. Um desafio efetivo teria que começar mostrando que o ostensivo "realismo" do capitalismo não era absoluto, nada disso. Aqui Fisher se baseia nas teorias da ideologia desenvolvidas por Zizek e Alenka Zupancic. "O princípio da realidade" constitui a forma mais elevada de ideologia, escreveu Zupancic, "a ideologia que se apresenta como um fato empírico" - precisamente o "sentido comum" que tendemos a considerar como não ideológico. Uma ideologia se torna dominante ao se naturalizar, comentou Fisher, de modo que sua aparência não seja percebida como a expressão de interesses e valores particulares, mas como um fato estabelecido. 0 realismo capitalista procurou eliminar a própria categoria de valor ético e instalar, em seu lugar, uma "ontologia dos negócios", na qual é óbvio que

${ }^{36}$ Capitalist Realism, p. 7-09. 
tudo, incluindo educação e saúde, deve ser administrado como uma empresa. 0 objetivo de uma política radical seria revelar as contingências ocultas por essa "aparência de empresa" como ordem natural. Uma estratégia - que Fisher baseava na leitura de Lacan por Zizek era invocar os "Reais" subjacentes à "realidade" que o capitalismo apresenta (o Real sendo, para Lacan, o que qualquer "realidade" deve suprimir) ${ }^{37}$.

Fisher definia três "Reais" subjacentes. Primeiro, a catástrofe ambiental, que o realismo capitalista incorporou até certo ponto, como estratégia de marketing, mas cujas implicações reais eram traumáticas demais para o sistema reconhecer. Segundo, o sofrimento mental generalizado, agravado sob o regime neoliberal, que passa a gerenciá-lo através da privatização - tornando a saúde mental um problema individual, um fracasso em cumprir o imperativo capitalista-realista de "parecer e se sentir [sempre] bem". Terceiro, a proliferação da burocracia, que o neoliberalismo havia prometido abolir. 0 livro enfoca especialmente os dois últimos, já que a crise ambiental já estava sendo politizada, enquanto a saúde mental e a burocracia não. Ambos tem uma forte presença numa área da cultura com a qual Fisher tinha bastante experiência: a educação.

Realismo Capitalista pinta uma imagem inesquecível do corpo discente de Orpington, analisando sua aparente apatia como "impotência reflexiva" - o sentimento de que os estudantes não podiam fazer mais nada para que sua situação não se convertesse numa profecia auto-cumprida. Fisher diagnosticava uma forma de "hedonia depressiva" - não uma incapacidade de experimentar prazer, como normalmente é associado à depressão, mas uma incapacidade de fazer qualquer outra coisa, exceto persegui-lo. Havia uma sensação de que "algo estava faltando", mas não havia entendimento de que isso pudesse ser acessado além do princípio do prazer. Em vez disso, os estudantes caíam numa "lassidão hedonista". Fisher arriscava dizer que problemas comuns como o aumento da taxa de dislexia poderiam, de fato, ser sintomas de pós-lexia: os adolescentes podiam processar dados densos em imagens do capital sem necessidade de ler; o reconhecimento de um slogan, por exemplo, era suficiente para navegar no plano de uma tela. Os professores eram encarregados de mediar entre as demandas dos regimes disciplinares (horários de aulas, exames) e a subjetividade pós-alfabetizada de consumidores capitalistas tardios, num momento em que

${ }^{37}$ Capitalist Realism, p. 16, 14, 17-18. 
as famílias estavam cedendo às pressões de uma economia pós-fordista que exigia que ambos os pais trabalhassem fora, longas e longas horas por $\mathrm{dia}^{38}$.

Os valores dos quais a vida familiar dependia - obrigação, confiança, compromisso se tornavam obsoletos sob o regime pós-fordista, argumentava Fisher. 0 capitalismo exigia demais das famílias - que são o local de descanso, remédio para feridas psíquicas, local de renovação diária da força de trabalho -, mesmo que as prejudicasse: sobrecarregava os pais como fonte exclusiva de consolo afetivo, negando o tempo do convívio com os filhos. Ao mesmo tempo, no pós-fordismo, os antagonismos de classe foram internalizados, manifestando-se como sofrimento mental. Fisher citou as contribuições de Oliver James em The Selfish Capitalist (2008) sobre a propagação de distúrbios psicológicos, no mundo de língua inglesa, como uma praga invisível desde os anos 1980. Que paralelismos existem entre os níveis crescentes de doença mental e os novos padrões de avaliação do desempenho dos trabalhadores - a pressão burocrática implacável para definir metas e objetivos, tabular resultados e formular propostas, declarações de intenção, fundamentais para o que Deleuze chamou de sociedades de controle? Tomando de empréstimo, uma vez mais, as elaborações de Lacan por Zizek, Fisher apontava que o público implícito desses dados era o "grande Outro" do realismo capitalista, isto é, os consumidores imaginados pela propaganda e pelas relações públicas, e não indivíduos existentes (que, como na União Soviética, conheciam o que realmente estava acontecendo), não eram senão uma ficção coletiva proposta pelo campo social. Confrontados com a necessidade permanente de cumprir os requisitos burocráticos e de vigilância - processos de revisão, relatórios anuais, avaliação de pesquisas -, os professores, sob o realismo capitalista, refletiam de volta para os alunos, como num espelho, sua própria impotência.

0 realismo capitalista não havia sido minado pela crise de 2008, concluiu Fisher - os resgates bancários foram uma afirmação em massa de que "não há alternativa". Mas o neoliberalismo havia sido desacreditado; não detinha mais o mesmo impulso confiante à frente. A crise conduziu a um abrandamento da paralisia mental: o cenário político estava repleto de "escombros ideológicos", abrindo espaço para um novo anticapitalismo, "uma renovação que não seria um retorno". Tratava-se de basear-se nos desejos que o neoliberalismo havia gerado, mas não conseguia satisfazer - por exemplo, o desejo de redução da burocracia. A demanda central de Fisher era por uma greve contra os tipos de

\footnotetext{
${ }^{38}$ Capitalist Realism, p. 21-2, 25-6. Fisher esclareceu a distinção entre fordismo - miticamente definido pela decisão de Henry Ford de pagar seus trabalhadores o suficiente para que eles pudessem comprar seus carros - e pós-fordismo através de uma comparação entre os filmes de gângster de Scorsese e Coppola, por um lado, e Heat, de Michael Mann, por outro.
} 
auditoria tidos como imprescindíveis para o trabalho pós-fordista. 0 professorado devia atacar retirando seu trabalho das maquinarias da autovigilância e da reprodução do gerencialismo. Os problemas de saúde mental deveriam se converter em antagonismos efetivos, o descontentamento a ser canalizado contra o capital, que é sua verdadeira causa. Um novo regime de racionamento poderia enfrentar os dois males da crise ambiental e da cultura consumista. 0 livro concluía com uma clara nota de otimismo, com a ideia de que a onipresença do realismo capitalista sugeria que mesmo breves vislumbres de dissidência poderiam ter um grande efeito: "um evento minúsculo poderia abrir um buraco na cortina cinza da reação que marcou o horizonte de possibilidades sob o realismo capitalista. Partindo de uma situação em que nada pode ocorrer, de repente tudo é novamente possível”39.

\section{0 início de um movimento?}

A singularidade de Realismo Capitalista não residia apenas nos traços mais gerais de suas análises, por mais poderosas que fossem, mas na força polêmica com a qual enfrentava as repercussões afetivas do neoliberalismo. Essa potência foi sentida imediatamente por aqueles que atingiram a maioridade sob o governo neoliberal, uma geração para a qual, como assinalou Fisher, o "capitalismo ocupava integralmente os horizontes do pensável" 40 . Para um jovem escritor, que se tornaria um futuro colaborador da Zero Books, era "um chamado espiritual às armas", "que diagnosticava o problema neoliberal e reimaginava a solução socialista com a força de uma revelação", contornando anos de "cobertura pósmoderna" para oferecer uma base para a ação e uma razão para ter esperança; depois de tanto tempo debaixo d'água, "sentíamos que voltávamos à superfície para respirar" 41 . Enquanto Realismo Capitalista desenvolvia temas de Jameson e Zizek, baseando-se neles, carregava, além disso, uma carga emocional ausente nos escritos desses últimos, uma sensação de que o autor vivenciava profundamente esse mal-estar contemporâneo, seja através da experiência de seus alunos, seja das pessoas privadas de apoio que haviam colapsado sob as "condições terrivelmente instáveis do pós-fordismo". Zizek mesmo

\footnotetext{
${ }^{39}$ Capitalist Realism, p. 81.

${ }^{40}$ Capitalist Realism, p. 08.

${ }^{41}$ Niven, "Mark Fisher, 1968-2017".
} 
endossou o livro como "simplesmente o melhor diagnóstico sobre o imbróglio em que nos metemos" 42 .

Apenas um ano depois de sua publicação, protestos estudantis eclodiram em todo o Reino Unido contra os aumentos nas taxas de matrícula impostas pela nova coalizão liberalconservadora. Entusiasmado pela repentina eflorescência, Fisher descreveu as ocupações "que brotavam em todos os lugares como flores silvestres inesperadas"43. "A única coisa com a qual eu posso comparar a situação atual", escreveu em K-Punk, depois de se juntar aos protestos, é com a saída de um estado de depressão profunda. Esse foi o primeiro de uma série de eventos desestabilizadores na política britânica - desordem nas ruas, escândalos nos altos escalões - que Fisher examinou com a esperança de uma mudança no clima político, o tempo todo refletindo sobre a persistência do neoliberalismo ("arrasta-se como um zumbi, mas, como bem sabem os fãs de filmes de zumbis, às vezes é mais difícil matar um zumbi do que uma pessoa viva"44). Contribuindo para a renovação das ações de oposição, Fisher escreveu e falou profusamente em reuniões e eventos durante esse período, produzindo uma ampla variedade de postagens em seu blog e artigos politicamente comprometidos sobre a fortuna e as estratégias dos movimentos de protesto; sobre austeridade, sobre o estado de bem-estar e o governo conservador; sobre o capitalismo comunicativo e a tecnologia; sobre neoliberalismo e democracia.

O sucesso inesperado de Realismo Capitalista transformou-o no principal título da nova editora de Goddard, Zero Books, e o pioneiro de uma série de livros sucessivos lançados por outros intelectuais de esquerda vindos da blogosfera: The Meaning of David Cameron (2010), de Richard Seymour, One-Dimensional Woman (2009), de Nina Power, e Militant Modernism (2009), de Owen Hatherley. Intimamente envolvido no projeto, o toque editorial de Fisher era inconfundível, expressando-se no manifesto da editora, que antagonizava com o "anti-intelectualismo cretino" e o "conformismo banal" da cultura contemporânea e afirmava seu compromisso com uma obra que fosse "intelectual sem ser acadêmica, popular sem ser populista". 0 objetivo era fundar um "espaço paralelo, entre a teoria e a cultura popular, entre o ciberespaço e a universidade" 45 .

Fisher voltou a fazer parte, uma vez mais, de uma animada constelação intelectual, agora mais expressivamente política, equivalente talvez à subcultura de esquerda que

\footnotetext{
${ }^{42}$ Capitalist Realism, p. 37. 0 depoimento de Zizek consta na contracapa do livro.

$43 \mathrm{Blog}$, "Winter of discontent 2.0: notes on a month of militancy", 13 de dezembro de 2010, K-Punk, p. 476.

44 "How to kill a zombie: strategizing the end of neoliberalism", OpenDemocracy, 18 de julho de 2013, K-Punk, p. 539.

45 “Zer0 Books statement”, 2009, K-Punk, p. 103; entrevista com Rowan Wilson, K-Punk, p. 630.
} 
surgiu no Brooklyn durante a mesma época, igualmente estimulada pelos protestos após a crise financeira. Nos dois casos, surgia uma nova geração de intelectuais com a sensação de que, no jornalismo, no mundo editorial e na academia existentes, não havia espaço disponível para pessoas como eles, que estavam dispostos a desenvolver suas próprias instituições. Entre outras distinções, a manifestação londrina do fenômeno era bastante mais acanhada e empobrecida, refletindo o impacto de 30 anos de comercialização e austeridade nas universidades e no cenário cultural; por necessidade, era menos orientada para o jornalismo de prestígio e seus meios preferidos eram os blogs, livros semelhantes a panfletos e, posteriormente, os podcasts e os vídeos.

\section{Transições}

Em 2010, falando sobre sua sua trajetória desde os tempos da CCRU, Fisher observou que "trabalhar no setor público na Grã-Bretanha de Tony Blair me fez ver que o capitalismo neoliberal não se encaixava no modelo aceleracionista", ao contrário, a pseudomercantilização estava gerando burocracia. Suas experiências como professor e ativista sindical, combinadas com o encontro tardio com os escritos de Zizek, "me levaram a uma posição política diferente" 46 . No ano seguinte - agora casado, pai de um bebê -, ele defendeu que os movimentos Occupy teriam de se transformar em "organizações fortes", com "uma agenda positiva", caso quisessem ter algum impacto duradouro ${ }^{47}$. Fisher se filiou ao Partido Trabalhista, naquele momento, na oposição - e liderado por Edward Miliband -, embora insistisse na necessidade de construir uma força extra-parlamentar forte o suficiente para se tornar uma influência dominante sobre o Parlamento. Diagnosticando o impasse político, era partidário de que a esquerda assumisse um caráter mais agressivo, substituindo sua posição reativa por uma postura mais propositiva. Em 2011, redigiu um artigo com seu amigo e aliado Jeremy Gilbert para Compass, uma think tank da esquerda trabalhista, pedindo que o partido (com o direcionamento posterior ao Novo Trabalhismo ainda a definir) se modernizasse com um programa de renovação democrática. Foi publicado três anos depois, em forma de um panfleto ${ }^{48}$.

\footnotetext{
${ }^{46}$ Entrevista com Rowan Wilson, K-Punk, p. 629-30.

47 “Capitalism Realism: Interviewed by Richard Capes”, 2011, K-Punk, p. 653.

48 "Reclaim Modernity: beyond markets, beyond machines", Londres, 2014; veja-se também a entrevista com Richard Capes, em M. Fisher, K-Punk: the collected and unpublished writings of Mark Fisher (2004-2016), cit., p. $658,656$.
} 
As teses centrais de Reclaim Modernity podem ser lidas como notas para um segundo volume de Realismo Capitalista. Críticos da "desastrosa estratégia" de Tony Blair de intensificar o projeto neoliberal iniciado por Callaghan e Thatcher, os autores se concentraram na proliferação da burocracia que essa estratégia havia produzido e em seu fracasso em gerar inovação cultural. Ao contrário do liberalismo clássico - eles argumentavam -, o neoliberalismo assume a tarefa de defender as relações competitivas em todas e em cada uma das esferas sociais, produzindo uma sensação opressora de obrigação e intrusão, inclusive em campos de atividade, como saúde e educação, onde as práticas de trabalho são instintivamente colaborativas. A esquerda "perderia uma oportunidade histórica" se permitisse que "o sentimento antiburocrático resultante fosse capturado e explorado pelos populistas de direita". 0 trabalhismo deveria "adotar uma postura clara, tanto na prática quanto na polêmica pública, contra esse aspecto impopular e improdutivo da cultura capitalista contemporânea"49.

No lugar do modelo neoliberal, a esquerda deveria construir instituições que permitissem que os relacionamentos cooperativos e colaborativos maximizassem sua eficiência e seus resultados de maneira distinta. Baseando-se em The Long Revolution (1965), de Raymond Williams, Fisher e Gilbert argumentavam que a educação deveria incluir práticas autênticas de tomada de decisões coletivas. As instituições do setor público deveriam ser responsáveis, livres das exigências burocráticas, mas protegidas dos predadores corporativos ${ }^{50} .0$ destino da cultura musical no Reino Unido - agora paralisada, quando já havia sido um centro mundial de inovação - mostrava o que ocorria quando o capital transformava uma matriz geral da criatividade coletiva numa máquina de gerar lucro, promovendo formas culturais homogeneizadas e conservadoras, parasitando as novas formas geradas em outros lugares ${ }^{51}$. As descobertas musicais produzidas nas décadas anteriores haviam se baseado num apoio indireto mediante provisões universais de um estado social-democrata, o que oferece um modelo para entender as condições de possibilidade da criatividade social em vários setores, especialmente naqueles da "economia do conhecimento": "Quem sabe como seria a cultura na qual a Internet coexistisse com uma forte provisão social?"52.

\footnotetext{
${ }^{49}$ Fisher and Gilbert, Reclaim Modernity, p. 12-13, 25.

50 Fisher and Gilbert, Reclaim Modernity, p. 25.

${ }^{51}$ Formal e genericamente, Reclaim Modernity argumenta que poucos produtos da atual "era de ouro" de nossa televisão foram além das convenções do suspense, da comédia de situação ou das aventuras de ação - o mundo ainda espera para ver o que pode ser genuinamente experimental na televisão do século XXI, p. 20.

52 Fisher and Gilbert, Reclaim Modernity, p. 16.
} 
Até certo ponto surpreendente, os argumentos de Fisher durante esse último período de sua atividade política eram a contrapartida das intervenções típicas de Hall durante o período anterior do governo conservador. Fisher argumentava que a esquerda precisava deixar de lutar em terrenos antigos, adaptar-se às novas composições sociais e de classe, abordar os desejos e as frustrações que fizeram com que o neoliberalismo tivesse apoio popular, conectar-se aos imperativos da cultura, resolver as equações em torno do gerencialismo e da burocracia estatal e recusar ceder a liberdade, o pluralismo e, sobretudo, a modernidade, à direita. Ambos os pensadores não prestavam atenção ao cenário internacional e à política externa. Na atenção que prestava ao discurso e à ideologia, aos modos de representação construídos nos meios de comunicação e à criação de um sentido comum, os escritos políticos de Fisher sempre compartilharam, em boa medida, o terreno metodológico ocupado por Hall. Mas isso agora se estendia a muitas de suas conclusões. Operando num momento diferente e com uma sensibilidade contrastante, os argumentos de Fisher não podiam passar por acomodatícios - como haviam sido os escritos de Hall, ao seu tempo -, dado que seu rechaço do status quo era demasiado visceral. Quando os cortes de benefícios foram aprovados em 2013, ele não hesitou em condenar a atmosfera de "decadência mortífera e desapegada" que permeava um Partido Trabalhista "que há muito tempo havia esquecido por que demônios queria ganhar as eleições" 53 .

A interação entre disposição intelectual e circunstâncias políticas converteu Fisher, em alguns aspectos, numa figura singular, pouco ortodoxa, que trabalhava em relativo isolamento das tradições das quais ele era um herdeiro natural. Emergindo num período de desordem e desagregação da esquerda e partindo do jornalismo musical e da teoria francesa, o leque de referências que ele desenvolveu foi, em grande parte, um panteão de entusiasmos pessoais. Nesses últimos anos, no entanto, quando sua atenção se voltou, pela primeira vez, aos aspectos práticos da renovação, seu trabalho se tornou novamente alerta aos antecedentes e, em particular, às suas convergências com Hall. Um estímulo para essa percepção veio de duas obras que o cineasta John Akomfrah dedicou a Hall e seu legado: The Unfinished Conversation (2012) e The Stuart Hall Project (2013). Fisher falou em algumas exibições deste último e, motivado por essas circunstâncias, escreveu um ensaio em que expressava sua admiração por Hall.

Um ensaio de Fisher, "A privatização do estresse", apareceu na mesma edição de Soundings (a revista que Hall cofundou com Michael Rustin e Doreen Massey), bem como

${ }^{53}$ Blog, 'The happiness of Margaret Thatcher', 8 de abril 2013, K-Punk, p. 532. 
"The neoliberal revolution", o último ensaio político de Hall ${ }^{54}$. Hall morreu em fevereiro de 2014, depois de um longo período enfermo. Um diálogo entre os dois nunca chegou a ocorrer. No trabalho de Fisher, no entanto, Hall estava se tornando um interlocutor significativo. Embora os escritos de Fisher estivessem dominados por uma visão lúgubre da hegemonia neoliberal, ele se interessou cada vez mais pelos modos através dos quais teria sido alterada a história política que ele próprio havia vivenciado. Aqui Hall também o incentivou. "A maneira de evitar a nostalgia", escreveu Fisher num ensaio publicado em 2014, "é procurar as possibilidades perdidas em qualquer época e o trabalho de Hall, desde seus primeiros escritos sobre cool jazz e Colin MacInnes, no final da década de 1950, até seus ensaios incluídos em New Times: the changing face of politics in the 1990s (1989), no final dos anos 1980, nos alertaram para um fracasso persistente no momento de estabelecer conexões entre a política de esquerda e a cultura popular". 0 socialismo, refletia Fisher, tem sido incapaz de lidar com as energias que provinham do jazz, da nova contracultura e do punk e, ao invés disso, ficou preso num "tradicionalismo retrógrado, que não tem nenhum gancho no campo libidinal do capitalismo pós-fordista”55.

Enquanto redigia Reclaim Modernity, Fisher esperava publicar um segundo livro em 2011, reunindo seus escritos sobre "hauntologia" 56 e futuros perdidos, produzidos a partir de 2006. Ao final, exigências de vários tipos fizeram com que Ghosts of My Life não aparecesse antes de 2014. Como explicou na introdução, Fisher acreditava que a última década, demarcada a partir de 2003, seria reconhecida como o pior período para a cultura popular no Reino Unido desde a década de 1950. Mas havia traços de outras possibilidades e Ghosts of My Life era uma tentativa de abordar algumas delas. Era uma coletânea robusta, que continha alguns de seus melhores textos sobre música, televisão, literatura e cinema, e suas partes díspares compunham um réquiem para um futuro que não havia se materializado. Os vários escritos de Fisher se organizavam em torno de uma sensação (definida a partir de uma frase que havia reparado na obra de Franco Berardi): o "lento cancelamento do futuro" promovido pelo neoliberalismo ${ }^{57}$.

No relato de Fisher, que escancara o selo autobiográfico implícito no título do livro, a desaceleração cultural concomitante se manifestava principalmente na música popular. Os

\footnotetext{
54 Ambos os ensaios foram publicados em Soundings, núm. 48, verão de 2011.

55 Gavin Butt, Kodwo Eshun e Mark Fisher, eds, Post-Punk Then and Now, Londres, 2016, p. 101, 110.

56 Em inglês, o termo ressoa também como "ontology" (ontologia) e "anthology" (antologia). Essa semelhança (ou oscilação) fonética dá uma riqueza adicional à expressão, tornando-a ainda mais sugestiva, bem como mais pertinente ao campo de preocupações de Fisher. Em português, a tradução que tem se afirmado e vem se tornando mais frequente é "espectrologia" [N.T.].

${ }^{57}$ Ghosts of My Life, p. 6.
} 
argumentos sobre sua "desaceleração" foram objeto de controvérsias constantes em sua região da blogosfera. A música eletrônica que antes havia sido "tão furiosamente inventiva" caíra vítima das mesmas condições de entropia prevalecentes em outros lugares. No entanto, Fisher se entusiasmava com vários músicos contemporâneos - entre eles, Burial, The Caretaker e William Basinski -, em cuja obra sentia uma disposição para recusar os limites do realismo capitalista. Reaproveitando a noção de hauntologia - de Jacques Derrida, elaborada em Spectres de Marx (1993) - para descrever a presença espectral do "amanhã de ontem", empregava-a para delinear um gênero contemporâneo definido mais por impulso do que por estilo. Em suas texturas melancólicas de loops, ecos e samples crepitantes, Fisher escutava o futuro perdido de uma época mais esperançosa.

\section{Acossado}

Quando Ghosts of My Life ainda estava no prelo, o envolvimento de Fisher com a política digital atingiu um ponto de inflexão doloroso. Na medida em que os movimentos estudantis e contra as políticas de austeridade perdiam força, alguns setores do ativismo voltaram suas energias contra si mesmos. "Neste verão, considerei seriamente a possibilidade de me retirar de qualquer envolvimento com política", começa a crítica de Fisher à cultura de denúncias on-line em "Sair do Castelo do Vampiro". "Exausto devido ao excesso de trabalho, incapaz de qualquer atividade produtiva, me encontrei vagabundeando pelas redes sociais, sentindo como meu cansaço e minha depressão aumentavam". Um pouco antes, nesse mesmo ano, ele havia se retirado das tempestades de esquerda no Twitter, nas quais personagens concretos eram "expostos" e condenados; o que diziam, às vezes, poderia ser censurável, mas, no entanto, "a maneira pela qual foram pessoalmente difamados e perseguidos deixou uma sensação residual horrível". "A razão pela qual não me manifestei sobre nenhum desses incidentes, tenho vergonha de dizer, foi o medo que tive. Os valentões estavam na outra parte do playground. Eu não queria atrair a atenção deles para mim". Os violentos ataques por parte das redes sociais de esquerda contra Russell Brand, o cômico inglês que desafiou o apresentador do Newsnight, Jeremy Paxman, fizeramno mudar de ideia. A resposta exasperada de Fisher analisava as "formações libidinaisdiscursivas" que haviam conduzido a essa "circunstância desmoralizante": "Dizem-se de esquerda, mas, como o episódio de Brand deixou claro, são, sob muitos aspectos, sinais de que a esquerda, definida como um agente da luta de classes, praticamente desapareceu". A 
nova cultura de denúncias estava sustentada por uma manifestação perniciosa da política identitária, na qual a mera menção à classe social era tratada agora como se implicasse minimizar a importância de raça e gênero. Contra o "identitarianismo", Fisher invocava a tradição dos Estudos Culturais de Hall, citando a obra de John Akomfrah. Parte da importância dessa tradição era ter resistido ao "essencialismo identitário" - "reconhecer que não há identidades, apenas desejos, interesses e identificações. [...] a questão era tratar qualquer articulação como provisória e dotada de plasticidade"58.

Comumente caricaturizado ou mal-interpretado, o ensaio recebeu uma resposta online violenta, provocando - numa ironia - o mesmo tipo de comportamento que procurava analisar. Muito além de quaisquer limitações em seu argumento - afinal, foi escrito durante um período de depressão -, a postura assumida contra as crueldades dessa cultura era, de uma só vez, valente e clarividente. 0 mundo virtual, que havia sido fonte de excitação desde os dias do CCRU, havia proporcionado a Fisher, desde muito tempo, um refúgio e uma arena para seu talento. Contemplar como se convertia numa patologia, e depois sentir-se obrigado a exilar-se dele - a partir de então retirou-se das redes sociais, seus posts no blog se tornaram infrequentes e, logo depois, minguantes - deve ter sido algo muito difícil.

\section{Escritos coligidos}

Os temas e as preocupações dos livros de Fisher aparecem como leitmotivs desta nova coleção. Com cerca de 800 páginas, reúne a maior parte dos escritos que Fisher produziu durante o período, mapeando o território desde o início de K-Punk até seus últimos trabalhos, do final de 2016; está prometido um volume independente, com textos anteriores a 2004. Dos seus 140 itens, mais da metade são procedentes do próprio K-Punk e o restante são contribuições para diversos tipos de publicações (jornais on-line e off-line, revistas de arte, música e política), entrevistas dadas ao longo do período, e alguns poucos itens singulares, incluindo um esboço do que seria a introdução a Comunismo Ácido, um trabalho que permaneceu inconcluso em razão de sua morte. É uma seleção extensa, embora não exaustiva. Estão ausentes uma série de peças de interesse filosófico e político, incluindo sua resenha de Valences of the Dialectic (2009), de Jameson, publicada em Mute, em 2010, bem como algumas peças mais extensas de jornalismo musical. Essas omissões são o

${ }^{58}$ Fisher, "Exiting the Vampire Castle", The North Star, 22 de novembro de 2013, K-Punk, p. 737, 740-1, 744. 
lamentável resultado de preferências editoriais tácitas, muito embora se deva notar que a obra de Fisher representa um desafio para qualquer organização, com muitas de suas ideias e seus melhores insights espalhados por reflexões transitórias. Inexplicavelmente sem um índice, a coleção é ordenada por temas para ajudar na navegação, mas isso tem suas desvantagens: não acompanha a propensão de Fisher de tratar filmes, música, autobiografia, teoria, política e sociedade em conjunto, enquanto que a ruptura da cronologia impede o exercício de rastrear o movimento de seu pensamento.

Uma coletânea assim desafia qualquer resumo. Contém apreciação e crítica cultural, reflexões sobre ideologia e estratégia política, exame minucioso da paisagem midiática e evisceração da política governamental, bem como meditações sobre as texturas da experiência contemporânea. A coleção, da mesma maneira, abriga uma variedade de formatos. Os escritos procedentes do blog são os mais informais, dado que são respostas a fatos efêmeros, àquilo que Fisher vinha assistindo, lendo ou ouvindo, discussões dentro do ambiente on-line em que ele se movimentava. Ler suas reflexões heterogêneas é observar suas ideias em processo de formação, seguir as peregrinações de uma inteligência única e generosa. 0 tom dominante é plangente, mas há também flashes de euforia. Um emocionante cronista dos tristes tropiques da Grã-Bretanha neoliberal, Fisher também se dedicou a procurar brechas de possibilidades (ou possibilidades através de certas brechas) e sonhar durante uma seca de pensamentos novos. Fervoroso em suas convicções culturais, ele também conservava uma abertura para encontrar alguma coisa valiosa em lugares inesperados, com textos que registram frequentemente essa emoção da descoberta. Sua escritura, que, em sua decodificação do contemporâneo pode alcançar uma qualidade quase numinosa, dotando os destroços da vida cotidiana de significado e importância, estimula uma emoção familiar.

Cumulativamente, a seleção marca os altos e baixos, tanto intelectuais e políticos quanto emocionais e financeiros, de uma vida de escritor. A progressão da carreira de Fisher após Realismo Capitalista levou a um número crescente de encargos. 0 novo clima era um pouco mais receptivo à sua escritura; ainda que Fisher continuasse sendo uma figura marginal, ele começou a contribuir para uma série de publicações culturais e de tendências de esquerda, incluindo um renovado The New Statement. Não que a vida como escritor freelancer fosse menos precária: numa entrevista, descreve como teve que "continuar trabalhando a um ritmo infernal para manter a cabeça fora d'água", enquanto que, numa nota de um minucioso artigo sobre elitismo e populismo, lamentava que "o tempo 
fragmentado e dividido da precariedade" o impedisse de trabalhar em "projetos mais longos"59. Boa parte do que Fisher produziu em formatos curtos era crítica cultural. Uma ampla gama do que se apresenta aqui mostra uma afeição particular por formatos e gêneros populares e pulp. Ballard, Lovecraft, Lynch e Cronenberg eram suas pedras de toque. 0 realismo, em qualquer meio, estimulou, de fato, pouco interesse. Com exceção do cinema, ocupou-se amplamente com a cultura britânica. Implacável em relação a boa parte da televisão e da música pop atuais - em críticas de uma cultura contemporânea degradada que poderiam estar atreladas à tradição da Kulturkritik -, se opõe ao gosto cultural elevado, à "condescendência cognitiva dos instruídos do centro de Londres", a respeito dos quais se lamenta num texto publicado por ocasião da morte de Ballard, em 200960. Desdenhando o empirismo nativo, com sua aversão às ideias, também promoveu seu próprio cânone teórico, procedente, em grande medida, das fileiras da filosofia continental.

O pós-punk emerge como uma de suas lealdades culturais mais importantes. Embora celebrasse a cultura do consenso do pós-guerra, Fisher se sentia visceralmente atraído por obras forjadas no tumulto de sua desintegração. Jovem demais para ter vivido a primeira fase do movimento punk, ele havia atingido a maioridade escutando uma trilha sonora de desvios, de rupturas em relação às formas anteriores, que instilaram nele a crença de que o pop é algo mais do que um "prazer agradável". Um post do blog insiste que "mais ou menos tudo o que escrevi ou participei foi, em certo sentido, uma tentativa de manter minha fidelidade com o 'evento pós-punk"'61. Três artigos sobre a lendária banda pós-punk The Fall, escritos entre 2005 e 2006, indicam dois sentidos dessa afirmação. Ao elogiar sua refutação de que qualquer noção de experimentalismo e sofisticação não fossem próprios da classe trabalhadora, Fisher também prestou homenagem ao impressionante efeito brechtiano que o trabalho da banda teve sobre ele próprio. Isso era, afinal de contas, o que o próprio Fisher representava - ele estava mais próximo, em alguns aspectos, dos artistas que admirava do que dos colegas escritores de esquerda -, bem como aquilo que sua obra, em grande medida, procurava conjurar. Como declarou em Realismo Capitalista, "a política emancipatória deve sempre destruir a aparência de uma 'ordem natural', deve revelar que o que é apresentado como necessário e inevitável é uma simples contingência, assim como

\footnotetext{
${ }^{59}$ Entrevista com Rowan Wilson, K-Punk, p. 636; blog, "Precarity and paternalism”, 11 de fevereiro de 2010, K-Punk, p. 203. 60 "The Assassination of J. G. Ballard", Ballardian, 28 de abril de 2009, K-Punk, p. 73.

${ }^{61} \mathrm{Blog}$, "The Outside of everything now", 01 de maio de 2005, K-Punk, p. 298.
} 
deve fazer que aquilo que era previamente considerado impossível possa parecer alcançavel"62.

0 gênero pós-punk encarnava, para Fisher, o ideal de uma cultura, a uma só vez, popular e dedicada a criar o novo, uma combinação que ele começou a chamar de pulp e, depois, de modernismo popular. Acreditava que tal síntese prosperara com a difusão cultural, social e geográfica das formas e dos impulsos modernistas do período do pósguerra, em boa parte facilitada pelo crescente igualitarismo e por um robusto estado de bem-estar social - o que, em outras palavras, caracterizava os marcos e a infraestrutura culturais de sua juventude. Isso se contrapunha ao panorama contemporâneo, submetido à degradação da radioteledifusão pública, à reestratificação da cultura segundo linhas de classe e governada pela lógica infernal do populismo neoliberal: "Nos fizeram acreditar que tratar as pessoas como se fossem inteligentes é 'elitista', enquanto tratá-las como se fossem estúpidas é 'democrático'”63. 0 declínio do Channel 4, que, desde o início, "degenerou em profundidades tão embaraçosamente desonestas e covardes que estão muito além da paródia", era emblemático da mudança ${ }^{64}$. 0 ponto forte dos jornalistas musicais, que o inspiraram inicialmente, foi argumentar que se podia encontrar tanta sofisticação na música pop mais refinada quanto na alta cultura convencional, algo que Fisher faz numa variedade de textos exemplares incluídos nessa coleção. A seu ver, o espírito contemporâneo era o inverso disso, promovendo um nivelamento cultural cuja implicação era de que, ao contrário, nada merecia ser levado a sério.

No caso da cultura e da crítica, o percurso desta coleção de textos apresenta, em grande parte, uma elaboração e uma consolidação contínuas. 0 principal desenvolvimento que se exibe, no entanto, é político. Esse desenvolvimento é essencialmente sincrônico com a história mais ampla da esquerda britânica do período - que vai do Novo Trabalhismo e da inauguração da guerra ao terror, passa pelas crises econômicas e pela austeridade, até um revival de possibilidades e renascimentos tentativos. Fisher descartou sua posição de não se compromissar com princípios ("não vote, não os incentive") quando os conservadores voltaram ao poder em 2010, numa coalizão com os democratas liberais, e, a partir daí, se implicou cada vez mais na política cotidiana ${ }^{65}$. Suas esperanças se frustraram na eleição de 2015, quando esperava celebrar a vitória de Corbyn. Em seu último post, inacabado, ele

\footnotetext{
${ }^{62}$ Fisher, Capitalist Realism, p. 17.

${ }^{63}$ Blog, "Precarity and paternalism", 11 de fevereiro de 2010, K-Punk, p. 200

64 "Classless broadcasting: Benefits Street", New Humanist, 17 de fevereiro de 2014, K-Punk, p. 238.

65 “Don't vote, don't encourage them", K-Punk, p. 429.
} 
descreve Donald Trump e o Brexit como "enraizados no anseio de um passado idealizado e na negação das complexidades e perplexidades do presente"66.

No últimos anos, os escritos de Fisher registram flutuações em suas esperanças superestimações periódicas que denotam o desejo de algo - e o arriscado emaranhado dessas ideias com seu próprio bem-estar pessoal. Um post escrito pouco antes das eleições de 2015 relata como lutou para continuar escrevendo no ano anterior. Ele achava que, após a "euforia inicial da dissidência", o país gradualmente se afundara num "nevoeiro de desespero". Recuperando um aumento repentino de humor, ele atribuiu parcialmente a mudança ao advento do Syriza, do Podemos e do Partido Nacional Escocês. Em linhas que abordam o clima mais amplo, embora pareçam falar mais de sua própria depressão, ele escreve sobre o sentimento de que "o bloqueio psíquico que nos impede de pensar e agir está aumentando". Num post subsequente, após uma segunda vitória dos conservadores, ele permaneceu resoluto, aconselhando a seus leitores que não se desesperassem. Uma mudança internacional de grande escala estava ocorrendo, insistiu, "ainda que não tenha atingido uma Inglaterra afundada na tristeza e na mediocridade" 67.

\section{A última utopia}

Fisher morava fora de Londres nessa época, tendo se mudado com a esposa e seu filho pequeno para a cidade litorânea de Felixstowe, na costa de Suffolk. Os processos históricos que moldaram sua vida estavam todos presentes nessa paisagem. Os guindastes dos contêineres do porto pairavam sobre a cidade, pareciam-lhe como os tripés marcianos de A Guerra dos Mundos (1898), de H. G. Wells, e "nos dizem muito sobre as transformações de capital e trabalho nos últimos quarenta anos". Essa reflexão aparece em The Weird and The Eerie, publicado no final de 2016, um mês antes de Fisher tirar a própria vida. Reunido numa época em que trabalhava como professor no departamento de Culturas Visuais da Goldsmith University, no sudeste de Londres, o delineamento dos modos estéticos expostos no título do livro inclui alguns de seus escritos mais elegantes, mas, à primeira vista, exibe uma diminuição da urgência política. Tendências familiares, no entanto, são discerníveis. Enquanto "o estranho" (weird) tende a indicar que "os conceitos e estruturas que empregamos anteriormente estão agora obsoletos", "o misterioso" (eerie) marca uma

\footnotetext{
${ }^{66}$ Blog, "Mannequin challenge”, 15 de novembro de 2016, K-Punk, p. 618.

67 Blog, "Pain now", 07 de maio de 2015, K-Punk, p. 569, 571; blog, “Abandon Hope (summer is coming)", 11 de maio de 2015 , K-Punk, p. 584.
} 
"libertação dos limites do que normalmente é considerado realidade". Nesta última obra, o sonho de um mundo que pudesse ser diferente adquire traços mais visionários e sobrenaturais, que apontam ao "que está além da percepção, cognição e experiência correntes"68. Essa tendência culmina em seu último escrito importante, que constitui agora a peça final dessa nova coletânea, a introdução ao que teria sido o seu quarto livro, Comunismo Ácido.

0 giro de pensamento que se produz aqui em relação a Realismo Capitalista é semelhante ao que distingue o Herbert Marcuse de O Homem Unidimensional (1964) do Herbert Marcuse de Eros e Civilização (1955), no qual Fisher se baseia. Sua tese central foi a que surgira em seus encontros com Hall: de que os anos 1960 e início dos anos 1970 haviam presenciado a incapacidade da esquerda em se conectar com a "euforia coletiva" da contracultura, deixando sua ânsia de liberdade e prazer ser colonizada pela direita ${ }^{69} .0$ comunismo ácido é o "espectro" dessa convergência fracassada; ele descreve esse apelo como "uma provocação e uma promessa, [...] de certo modo, uma piada com um propósito muito sério". Ainda que houvesse desprezado o movimento hippie, Fisher esboça a emergência de uma cultura que imaginava uma saída para a rotina. Numa passagem emotiva, ele se pergunta se a energia contra-revolucionária do neoliberalismo não seria, paradoxalmente, "um testemunho da escala da ameaça representada pelo espectro de uma sociedade que pudesse ser livre"70. Essas eram ideias que haviam germinado em discussões com Jeremy Gilbert e com o grupo autonomista Plan C. Hall faz uma última aparição, sonhando com um socialismo que pudesse se conectar com os sentimentos que havia detectado na música de Miles Davis.

A trajetória que Fisher percorre aqui representa uma certa mudança de perspectiva, tanto diacrônica quanto sincrônica, com seu campo de visão se estendendo desde o período pós-punk e, pela primeira vez, ampliando-se para além das costas britânicas, para nomear o golpe de estado de Pinochet, no Chile, em 1973, como o momento fundador do realismo capitalista. A redução da contracultura a imagens "icônicas" e "clássicos" da música operava para neutralizar as possibilidades reais que então haviam explodido, ele argumentava, pairando, acima de todas elas, a confluência entre o movimento pelos direitos civis, as lutas de classes, a organização feminista socialista e as ideias sobre alteração da consciência. Teoricamente, ainda que a relação entre cultura e política estivesse sujeita a flutuações em

${ }^{68}$ Mark Fisher, The Weird and the Eerie, Londres, 2017, p. 77.

69 "No romance without finance", Bamn: an unofficial magazine of Plan C, 09 de novembro de 2015, K-Punk, p. 424.

70 "Acid communism (Unfinished introduction)", K-Punk, p. 758-9. 
seus escritos - às vezes, a cultura é determinante, estabelecendo possibilidades imaginativas de ação; em outras, pode extinguir-se mediante a transformação política -, aqui ele visualiza sua convergência. Da mesma forma, ainda que, há muito tempo, houvesse apresentado sua própria experiência como testemunho do poder transformador das obras de arte, Fisher oferece, a respeito disso, uma visão ainda mais incrementada, localizando a possibilidade de um novo mundo em músicas dos Beatles e dos Temptations. Escrito num período de sérias dificuldades, Fisher deixa transparecer sua faceta mais utópica, enfatizando a promessa contínua de uma "nova humanidade, uma nova forma de ver, de pensar e de amar"71.

Essas passagens, junto com outras procedentes de textos anteriores, também presentes na coleção, agora nos dificultam a leitura. Um ensaio pessoal publicado em 2014 descreve o modo como Fisher pensava: que sua depressão havia se enredado em sua experiência da hierarquia social, orientando-o em torno de um sentimento de inutilidade que sentia ter sido criado, que lhe havia sido inculcado, bem como a dor de se encontrar num espaço entre classes sociais. Ambas as coisas, ele escreve, deixaram-no com a sensação de "não servir para nada"72. As pistas disso também podem ser encontradas em sua crítica cultural, em descrições da "raiva, da confusão e da vergonha", do "drama doloroso de se tornar algo que você não é"73. Um crítico convincente das maneiras pelas quais os problemas sociais e políticos são reduzidos à patologia pessoal, Fisher atribuía o controle de sua depressão à necessidade de percebê-la em termos menos individualizados ${ }^{74}$. Em certo sentido, isso também lhe proporcionou uma maneira de exteriorizar seu próprio sofrimento. A época contemporânea, no diagnóstico que ele nos deixou, era essencialmente depressiva, não apenas devido ao estado degradado do realismo capitalista, mas à situação da esquerda, à aceitação da austeridade pelo público e ao estado da nação. A Inglaterra em 2015, ele escreveu, é "possivelmente o país mais deprimido que já existiu na terra"75. No último post de seu blog, publicado agora pela primeira vez, não obstante, não se fez de rogado. Os tumultuosos acontecimentos políticos de 2016 demonstraram que a direita "recuou em sua reivindicação de modernidade", proporcionando "mais ímpeto para que a esquerda possa recuperá-la"76.

\footnotetext{
71 “Acid communism”, K-Punk, p. 754, 767.

72 "Good for nothing", Occupied Times, 19 de março de 2014, K-Punk, p. 747.

73 Blog, "Stand up, Nigel Barton”, 13 de junho de 2004, K-Punk, p. 116; Blog, “Ripley’s glam”, 1 de julho de 2006, K-Punk, p. 84.

${ }^{74}$ Após o inquérito [relativo à morte], sua esposa, Zoe Fisher, muito comovida, falou sobre como o NHS burocratizado e mercadologizado falhou em cuidar de Fisher. Ver: Adam Howlett, "Renowned writer and K-Punk blogger Mark Fisher", Ipswich Star, 18 de julho de 2017.

${ }^{75}$ Blog, "Democracy is joy", 13 de julho de 2015, K-Punk, p. 609.

${ }^{76} \mathrm{Blog}$, "Mannequin challenge", K-Punk, p. 623.
} 


\section{Referências}

CAMPAGNA, F.; CAMPLigLiO, E. (orgs.). What We Are Fighting For: a radical collective manifesto. London: Editorial Pluto Press, 2012.

CHILDREN of Men. Directed by Alfonso Cuarón. London: Universal Pictures, 2006. (109 min.), son., color.

DELEUZE, G.; GUATTARI, F. Anti-Oedipus. Paris: Éditions de Minuit, 1972.

DERRIDA, J. Spectres de Marx. Paris: Éditions Galileé, 1993.

ELLIOT, T.S. The Wasteland. New York: Boni and Liveright, 1922.

FISHER, M. Capitalist Realism. Is there no alternative? Winchester - UK; Washington EUA: Zero Books, 2009.

FISHER, M. Ghosts of My Life. Writings on depression, hauntology and lost futures. Winchester: Zero Books, 2014.

FISHER, M. The Weird and the Eerie. London: Repeater, 2016.

FISHER, M. Flatline Constructs. Gothic materialism and cybernetic theory-fiction. New York: Exmilitary, 2018.

FISHER, M.; AMBROSE, D. (eds.). K-Punk: the collected and unpublished writings of Mark Fisher (2004-2016). Londres: Repeater, 2018.

HALL, S. The Hard Road to Renewal: thatcherism and the crisis of the left. Londres, Nova York: Verso, 1988.

FISHER, M.. New Times: the changing face of politics in the 1990s. London: Lawrence and Wishart \& Marxism Today, 1989.

HALL, S.; WHANNEL, P. The Popular Arts. London: Hutchinson Educational, 1964.

HATHERLEY, O. Militant Modernism. London: Zero Books, 2009.

HOGGART, R. The Uses of Literacy: aspects of working-class life with special reference to publications and entertainments. London: Chatto and Windus, 1957.

JAMES, O. The Selfish Capitalist. London: Vermilion, 2008.

JAMESON, F. Valences of the Dialectic. London: Verso, 2009.

LAND, N. The Thirst for Annihilation: George Bataille and virulent nihilism. London, New York: Routledge, 1992.

LYOTARD, J. Économie Libidinale. Paris: Les Éditions de Minuit, 1974. 
MACKAY, R.; AVANESSIAN, A. (eds.). \#Accelerate\#. The Accelerationist Reader. Falmouth: Urbanomic, 2014.

MARCUSE, H. Eros and Civilization. Boston: Beacon Press, 1955.

MARCUSE, H. One-Dimensional Man. Boston: Beacon Press, 1964.

PLANT, S. The Most Radical Gesture: the Situationist International in a postmodern age. London, New York: Routledge, 1992.

PLANT, S. Zeros and Ones. Digital women + the new technoculture. London: Fourth Estate, 1997.

POWER, N. One-Dimensional Woman. London: Zero Books, 2009.

SEYMOUR, R. The Meaning of David Cameron. London: Zero Books, 2010.

THE UNFINISHED Conversation. Directed by John Akomfrah. London: Smoking Dogs Films, London Biennial, Tate Britain, 2012. (103 min.), son., color.

THE STUART Hall Project. Directed by John Akomfrah. London: Smoking Dogs Films,2013. (96 min., son., color.

WELLS, H. G. The War of The Worlds. London: William Heinemann, 1898.

WILLIAMS, R. The Long Revolution. Harmondsworth: Pelican, 1965.

ZIZEK, S. Welcome to the Desert of the Real. London: Verso, 2002.

ZIZEK, S. Iraq: the borrowed kettle. London: Verso, 2005.

\title{
K-Punk at large
}

\begin{abstract}
"K-Punk at large", translated here, was originally published in the New Left Review, edition 118, from July-August 2019. Simon Hammond, in this article, provides a broad overview of the work of English philosopher and cultural critic Mark Fisher (19682017), focusing on the K-Punk collection, launched in 2018. It examines the maturation of Fisher's work from Capitalist Realism (2009), his first book, to Acid Communism, the book he left only sketched, apprehending it in dialogue with Stuart Hall, in the tradition of English Cultural Studies.
\end{abstract}

\section{Key-words}

Mark Fisher. K-Punk. Capitalist realism. Acid communism. 


\section{Autor correspondente}

Fabrício Silveira

fabriciosilveira@terra.com.br

\section{Como citar}

HAMMOND, Simon. K-Punk ampliado. Tradução: Fabrício Silveira, Matheus Borges. Intexto, Porto Alegre, n. 52, e-108170, jan./dez. 2021. DOI: http://dx.doi.org/10.19132/1807-8583202152.108170

Recebido em 06/10/2020

Aceito em 07/11/2020 